\title{
Quercetin: A Promising Flavonoid with a Dynamic Ability to Treat Various Diseases, Infections, and Cancers
}

\author{
Aaron J. Smith, John Oertle, Dan Warren, Dino Prato* \\ Envita Medical Center, Scottsdale, AZ, USA \\ Email: ‘DinoPrato@envita.com
}

Received 19 January 2016; accepted 19 February 2016; published 22 February 2016

Copyright (C) 2016 by authors and Scientific Research Publishing Inc.

This work is licensed under the Creative Commons Attribution International License (CC BY). http://creativecommons.org/licenses/by/4.0/

c) (i) Open Access

\begin{abstract}
Quercetin is a multifaceted dietary flavonoid with a multitude of biologic activities that can be used to treat various ailments. These include cancer, bacterial and viral infections, cardiovascular disease, and diabetes. A greater emphasis on cancer is discussed within this paper by highlighting some of the beneficial qualities of quercetin without including other related dietary flavonoids and quercetin analogs. In vitro and in vivo analysis are evaluated without making recommendations on dosage, dosing regiments, or administration since quercetin has not been subjected to rigorous clinical trials despite the significant amount of research that has been conducted with quercetin.
\end{abstract}

Keywords

Quercetin, Cancer, Infection, Biomarkers, Diabetes, Mast Cell, Cardiovascular

\section{Introduction}

Quercetin is a flavonol, a type of flavonoid which is commonly present in various foods including onions, fruits, and vegetables [1] [2]. Quercetin, at nontoxic concentrations, is known to have a multitude of recognized biologic effects in which many of its mechanisms remain a mystery [3] [4]. Despite most of the information known about quercetin being based on in vitro and murine models, there is significant evidence that quercetin is a molecule with several biologically beneficial properties. These properties support quercetin's role as a treatment for oxidative damage, cancer, inflammation, bacterial and viral infections, cardiovascular disease, and diabetes. The evidence for each of these categories varies in the level that it has been investigated. Conclusive

"Corresponding author.

How to cite this paper: Smith, A.J., Oertle, J., Warren, D. and Prato, D. (2016) Quercetin: A Promising Flavonoid with a Dynamic Ability to Treat Various Diseases, Infections, and Cancers. Journal of Cancer Therapy, 7, 83-95.

http://dx.doi.org/10.4236/jct.2016.72010 
findings of quercetin's benefits, to our knowledge, has not completed all the rigors of pharmaceutical clinical trials. Although there are many quercetin analogs and dietary flavonoids with varying evidence to support their claims, this paper will focus exclusively on quercetin and its known mechanism and properties itself.

Quercetin derives its name from quercetum which means oak forest. It is a flavonoid that derives its name from flavus which means yellow. Quercetin's structure is derived from 2-phenylchoromen-4-one which is also classified as flavone. There are many proposed qualities that quercetin could potentially have in plant biology. These include plant protection from UV light, in addition to an impact on bacterial, viral, and fungal infections, as well as an enzyme inhibitor, a potential pollinator attractor, and plant hormone controllers [5].

\section{Bioavailability}

Some of the earliest analyses of quercetin's bioavailability after a single oral dose claimed the bioavailability to be approximately $2 \%$ [6]. By means of radiolabeled quercetin, the bioavailability was determined to be closer to 44.8\% associated with mouse blood plasma analysis [7]. However, since the half-life of radiolabeled carbon ranges between 11 - 28 hours, the bioavailability of quercetin might actually be higher than initially reported, especially if quercetin is continuously supplemented [8] [9]. Quercetin is universally known for its low toxicity as a natural product despite the limited information on dosing regiments.

\section{Antioxidant Capabilities}

Quercetin's ability to scavenge free radicals and bind to transition metal ions makes it considered a strong antioxidant [10]. This is due largely to the pharmacophores found within quercetin including a catechol group found in ring $\mathrm{B}$ [11]. Quercetin is the most potent scavenger of $\mathrm{O}_{2}^{-}$, and $\mathrm{ONOO}^{-}$[12]-[15] within the flavonoid family [16] [17] and its qualities as an antioxidant makes quercetin a strong lipid peroxidation inhibitor [18] [19]. In addition to its antioxidant properties, quercetin also increases glutathione concentrations [20] of which can inhibit free radical formation [21]. Quercetin itself is also a powerful free radical scavenging antioxidant [22]. The antioxidant properties of flavonoids like quercetin are often correlated with the reduction of rates of several chronic diseases including coronary heart disease, stroke, and diabetes [23] [24].

\section{Cancer}

The effect of quercetin on cancer is two-fold since it has direct anticancer properties in addition to chemopreventive properties. These findings are not without controversy since the intake of various substances rich in dietary flavonoids have not been shown to reduce cancer risk. Some of these dietary sources include black and green tea consumption [25] and red wine consumption [26] [27]. However, consumption of onions, which have among the highest concentration of quercetin and flavonols, were shown to reduce cancer risks in stomach, colon, and rectal cancers [28].

Diets high in quercetin are correlated with lower rates of stomach, colon, breast, and lung cancers [29]-[32]. Many of the studies associated with quercetin's effect on cancer are based on the chemical induction of cancer with either coadministration of quercetin or administration of quercetin after cancer was induced. Experimentation regarding the blocking of cancer formation with quercetin using TPA/methylcholanthrene showed quercetin was able to block cancer formation in low doses but not at high doses [33]. In another experiment involving the chemopreventive properties of quercetin on skin cancer, mice were administered quercetin 30 mins before the carcinogenic primer 12-O-tetradecanoyl phrobol-13-acetate [34]. Such inhibition of skin cancer formation suggests quercetin might be considered an effective agent of skin cancer prevention [35].

Although the mechanism associated with quercetin's chemopreventative and anticancer properties is unknown, there are interactions that could illuminate the mode of quercetin's beneficial characteristics with regard to its role in cancer treatment and prevention. Quercetin is a known phytoestrogen and has the potential to interact with estrogen responsive receptors including cannabinoid CBI receptor (CBI-R) [36] which can influence an inhibitory tone on cell growth [37] [38].

The mechanism for the chemopreventive properties of quercetin is unknown, but there are a few intercellular mechanisms that can advance the discussion. These models include the inhibition of nuclear factor- $\kappa \mathrm{B}(\mathrm{NF}-\kappa \mathrm{B})$ in addition to potentially involving the PI3K/Akt/IKK/NF- $\kappa \mathrm{B}$ signaling axis. This mechanism is consistent with other flavonoids that have NF- $\kappa \mathrm{B}$ inhibitors [39]-[41]. NF- $\kappa \mathrm{B}$, in particular, has been a target of interest in drug discovery using natural agents [42] [43]. Quercetin may work either by direct or indirect effects on NF- $\kappa$ B. 
$\mathrm{NF}-\kappa \mathrm{B}$ is stimulated by $\mathrm{I} \kappa \mathrm{B}$ kinase which is associated with either pro or anti-apoptotic pathway through regulation of the p53 gene [44]. However, quercetin is known to promote apoptosis of cancer cells similarly to other flavonoids [45]-[47]. This is done by a mechanism that may not involve a p53 signaling pathway [48]. Quercetin and other flavonoids are also able to inhibit PI3K/AKT axis in addition to inhibition of various PI3K isoforms [49]-[51]. However, there is still a significant amount of information that remains unknown, and there is a possibility to quercetin inhibits other kinases and enzymes other than PI3K and NF- $\kappa \mathrm{B}$ [52].

In vitro analysis of quercetin may have the ability to re-sensitize cancer cells to chemotherapy, in addition to reversing drug resistance associated with chemotherapy [53]-[57]. For example, quercetin can reserve tamoxifen resistance in breast cancer cells [58]. Other studies suggest that quercetin has the potential to potentiate other chemotherapies' effectiveness including agents such as topotecan, doxorubicin, cisplatin, ribavirin, tamoxifen, adriamycin, genistein, and carboxyamidotriazole [59]-[73].

Quercetin has the capability of inhibiting the transcription of heat shock protein (HSP) and hypoxia inducible factor-1 (HIF-1), essentially reducing the influence of a hypoxic cellular condition has on oncogenesis [74]. Quercetin also had an effect on the translocation of protein kinase $\mathrm{C} \delta(\mathrm{PKC} \delta)$ to the cellular membrane [74]. Hypoxia induced signaling involving heat shock factor (HSF) and HIF-1 are likely associated with PKC $\delta$ signaling [74]. Quercetin is also shown to inhibit tumor invasion and metastasis by suppression of the PKC $\delta / \mathrm{ERK} /$ AP-1-dependent matrix metalloproteinase-9 activation in breast cancer cells [75].

The anticancer activity of quercetin may involve downregulation of reactive oxygenated species (ROS) and TNFR1 levels [76]. PKC is essentially a housekeeping enzyme, but under conditions of increased oxidative stress, it can promote tumorigenesis and malignancy [77] [78]. It is important to note that oxidation of the $\mathrm{NH}_{2}$ terminal activates PKC but oxidation of the $\mathrm{COOH}$ terminal can inactivate PKC [79]. PKC's activity was shown to be down regulated after quercetin treatment in mice bearing Dalton's lymphoma [76]. Quercetin is said to modulate conventional, novel, and atypical PKC pathways [76].

Quercetin was also shown to induce apoptosis in non-small-cell lung cancer cell line A549 via a mechanism likely related to the upregulation of caspase 3 , a major gene associated with apoptosis [80]. Other evidence from the same study showed an increase in Bax, a major apoptotic protein in addition to a marked decrease in Bcl2, a major anti-apoptotic protein [80]. Quercetin also reduces titers of interaction interleukin 6 (IL-6), an inflammatory cytokine promotes cancer formation in a mechanism associated with downstream regulation of STAT-3 [80].

The effect of quercetin on cancer stem cells is still unknown, however, several studies have shown promise with proposed potential mechanisms of action regarding the effect of quercetin on cancer stem cells when co-administered with other chemotherapies. Cancer stem cells are unlike normal cells in that they undergo abnormal differentiation as well as a dysregulated self-renewal. It is thought that quercetin acts as an efflux pump inhibitor and increases the bioavailability of drugs through inhibition of BCRP, MRP1, and P-gp [81]. Thus, at non-toxic concentrations of quercetin, quercetin is thought to enhance chemotherapeutic effects of chemotherapy [81]. Leukemic progenitor cellular growth can also be influenced by quercetin by a mechanism associated with the transforming growth factor $\beta 1$ (TGF- $\beta 1$ ) in vitro [82]. TGF- $\beta 1$ has powerful hematopoietic regulatory properties [83]-[85], and depending on their stage progenitor differentiators, acts to either stimulate or inhibit the growth of noncancerous myeloid progenators [83] [86]-[89]. Quercetin similarly inhibits the growth of ovarian cancer cells by a mechanism associated with TGF- $\beta 1$ [90].

There are several identified biomarkers that quercetin can be effective with regard to treating cancer. Biomarkers associated with cancer stem cells (CSC) include ALDH-high, Oct4, Nestin, and Nanog [91]. Many of these biomarkers are transcription factors associated with the stemness of the cancer stem cells [91]. Biomarker HSP-27 was found to be inhibited in breast CSC by quercetin which correlates with observation that HSP-27 is involved in the suppression CSC population and the suppression stemness properties [92]. In head and neck cancer, quercetin was able to suppress ABCG2 and MDR1 inhibition of HSP-27 [93]. Pancreatic cancer can be affected by quercetin by cytotoxic action or by the inhibition of the biomarker associated with the Wnt $/ \beta$ catenin signaling in addition to chemosensitization to gemcitabine [94]. Pancreatic CSC biomarker ALDH can experience a decrease in action by quercetin in addition to quercetin's ability to potentially induce apoptosis in those cells [95]. Other known cancer biomarkers that can be targeted by quercetin include the potential biomarker of the egf-Pi3K-AKT pathway, the established biomarkers of Wnt/ $\beta$-catenin and estrogen receptor (ER), and the putative biomarkers JAK-STAT, Notch 1, and Notch 2 [96]-[101]. The induction of death receptor 5 (DR-5) and survivin suppression mark an additional two biomarkers that are affected by quercetin [102]. A more complete 
list of biomarkers affected by quercetin is presented in Table 1.

Photodynamic therapy can be a complementary treatment modality that can be administered before or after chemotherapy, radiotherapy, or surgery without adversely affecting other treatments [107] [108]. Photodynamic therapy involves the excitation of photosensitive molecules using visible light and a mechanism that also involves molecular oxygen [109] [110]. The creation of reactive oxygen species, including singlet oxygen, inside the cell by photodynamic therapy results in photo-damage and leads to cell death [111] [112]. HEp-2 cells showed significant sensitivity to photodynamic therapy and quercetin in concentrations of $50 \mu \mathrm{M}$ and $100 \mu \mathrm{M}$ independently [113]. However, the combination of photodynamic therapy and quercetin at a concentration of 50 $\mu \mathrm{M}$ and $100 \mu \mathrm{M}$ showed a significant decrease in cellular density as compared to the photodynamic therapy alone [113].

\section{Inhibition of Mast Cells}

Mast cells are derived from hematopoietic progenators that, depending on the microenviromental conditions, mature in tissue [114] [115]. Mast cells are known for their role as effector cells in allergic reaction [116]-[119] associated with their secretion of histamine, prostaglandin D2 $\left(\mathrm{PGD}_{2}\right)$, leukotrienes (LT), a variety of multifunctional cytokines, and proteolytic enzymes [120]-[122]. Inflammation via activation and recruitment of immune cells in addition to late-phase reactions describe the primary function mast cell secretions [123] [124]. Quercetin

Table 1. The following are a list of various biomarkers in cancer that are affected by quercetin.

\begin{tabular}{cc}
\hline Putative biomarkers & Citations \\
\hline ALDH high & {$[91][95]$} \\
Oct4 & {$[91]$} \\
Nestin & {$[91]$} \\
Nanog & {$[91]$} \\
HSP-27 & {$[92][93]$} \\
Wnt/ $\beta$ 'catenin & {$[94][100]$} \\
Egf-Pi3K-AKT pathway & {$[101]$} \\
ER & {$[96]$} \\
JAK-STAT & {$[98]$} \\
Notch 1 & {$[99]$} \\
Notch 2 & {$[99]$} \\
TNFR1 & {$[76]$} \\
PKC & {$[76]$} \\
HIF1 & {$[74]$} \\
NF- $\kappa$ B & {$[105]$} \\
PI3K & {$[106]$} \\
Pannabinoid receptor & {$[50][51]$} \\
Death Receptor & {$[102]$} \\
IGFin & {$[102]$} \\
\hline
\end{tabular}


has been shown to attenuate the activation of the transcription factor NF- $\kappa \mathrm{B}$ which in turn inhibits the downstream expression of TNF- $\alpha$, IL-1, IL-6, and IL-8 [41]. Activation of cytokines in mast cells via IgE-mediated mast cell activation was also inhibited by concentrated extract containing significant levels of quercetin [125].

\section{Bacterial Infections}

Quercetin alone or in combination with other supplements or antibiotics has been shown in vitro and in vivo to kill the bacterium. Quercetin alone has been shown to have antibacterial properties in vitro against Actinobacillus actinomycetemcomitans, Actinomyces naseslundii, Actinomyces viscosus, Fusobacterium nucleatum, and Porphyromonas gingivalis [126] [127]. Helicobacter pylori were shown to be sensitive to the antimicrobial effects of quercetin in both in vitro and in vivo studies [128]-[130]. Quercetin in combination of supplements morin and rutin and antibiotics including amoxicillin, ampicillin, cephradine, ceftriaxone, imipenem, and methicillin showed a synergistic effect against methicillin resistant Staphylococcus aureus (MRSA) in vitro [131]. A synergistic effect against MRSA was also seen when natural compounds quercetin and epigallocatechin gallate were administered together in vitro studies [132].

\section{Viral Infections}

There is mounting evidence that quercetin and its analogs have antiviral properties. Although there are many proposed mechanisms for how quercetin and its analogs accomplish their antiviral activity, a universal mechanism is unknown. This leads many to believe that the evidence suggests that quercetin might have multiple mechanisms of action depending on the type of virus and viral targets. Some of quercetin's earliest viral studies show quercetin has antiviral activity against enveloped viruses including herpes virus simplex 1, parainfluenza type 3, pseudorabies, and Sindbis [133] [134]. The mechanism of action may involve interference with viral nucleic acid synthesis. However, the suppression of hepatitis $C$ by quercetin is likely caused the inhibition of a multifunctional viral protease NS3 [135].

\section{Cardiovascular}

There are several cardiovascular benefits associated with quercetin. Much of the evidence remains in murine models and the mechanisms of action have not been resolved as of yet. The severity of ischemia-reperfusion had been reduced when mice were given $20 \mathrm{mg} / \mathrm{kg}$ of quercetin before clamping of the aorta and once again after reperfusion [136]. A $5 \mathrm{mg} / \mathrm{kg}$ single dose of quercetin was also able to reduce the effects of reperfusion damage in rats [137]. $50 \mathrm{mg} / \mathrm{kg}$ of quercetin has been shown to treat atherosclerosis in mice through a mechanism associated with the interference associated with foam cell formation and by reducing macrophage induced oxidant/proinflammatory response [138]. Quercetin has been determined to accumulate in human atherosclerosis lesions despite not being found in normal aort [139]. Quercetin is potentially an effective drug for the treatment of pulmonary arterial hypertension in part by a mechanism associated with the TrkA/AKT signaling pathway [140].

\section{Diabetes}

Although there is significant evidence of the effects of quercetin on diabetes and diabetic related ailments, the mechanism of action remains unknown. This includes the lowering of glucose in blood plasma, preservation of $\beta$-cell activity in the pancreas, glucose tolerance test normalization, in addition to protection against diabetic effects on mood, cognition, and renal functions in rat models [141]-[147]. Quercetin also acts to protect against high glucose induced damage and may also aid in improvements associated with vascular repair in addition to the promotion of the biological functions in endothelial progenitor cells [148]. In a small clinical study involving 34 men and women with either type 1 or type 2 diabetes with diabetic neuropathy, patients were given a topical treatment containing quercetin ascorbyl palmitate, and vitamin D3 or placebo three times a day for a period of four weeks [149]. Patients who used the quercetin topical treatment experienced improved quality of life in addition to a reduction of pain, numbness, and irritation [149].

\section{Discussion}

There is still much left to be discovered about the beneficial qualities of quercetin in all of the topics listed. The 
list of potential benefits of quercetin in this paper is not exhaustive, and there are likely more benefits to be discovered in the future. Although the intake of dietary flavonoids does little to exhibit the qualities listed in this paper, there is some evidence that quercetin supplements may induce the desired results. Since quercetin is poorly regulated, concentrations of quercetin from various kinds of extracts can lead to varying levels of other plant products which can lead to variability in the mass of pure quercetin in dosages. Some disreputable distributors of quercetin may not have quercetin in it at all. Nevertheless, a consistent dosage for each of the proposed benefits of quercetin remains contentious and should be left to the recommendation of physicians despite its remarkably low toxicity..

Quercetin is involved in a multitude of cellular functions and the human body likely evolved with consumption of dietary flavonoids like quercetin. The ubiquitous nature of quercetin in various biologic functions makes the resolution of the complete effects associated with the mechanisms of action of quercetin to be remarkably difficult. Quercetin's ubiquitous nature in effecting a variety of biological functions combined with research from various independent research groups has diminished the focus, often effecting follow up work, and has lead to a significant amount of knowledge pertaining quercetin to not reaching the depth of knowledge that would satisfy all the rigors of clinical trials. More research should be done to follow up on what is known about quercetin and further the knowledge to create a clear, and if possible, universal biochemical pathway or pathways associated with quercetin.

It is important to note that quercetin can act on a variety of different cancers that express biomarkers and molecular pathways described in this paper. A significant amount of research has resolved cancer to be more of a disease related to cellular mutation rather than based solely as a disease of tissue. For this reason, quercetin's mechanism or mechanisms of action can be utilized in various cancers that have similar genotypic or phenotypic expression of biomarkers and various molecular pathways.

\section{Conclusion}

It is clear that the research on quercetin may lead to potentially promising new treatment options for the various diseases discussed. More research is needed to develop a clear picture of how quercetin works from a biochemical standpoint. Extensive clinical research should follow up to determine whether or not quercetin can work in similar ways as described in various in vitro and murine models. This is particularly relevant with understanding the optimal dosage, frequency of dosages, and routes of administration. However, despite the low toxicity of quercetin and its ubiquitous nature as a dietary flavonoid, it is important to consult a physician to limit adverse events when used with other pharmacological substances.

\section{References}

[1] Sampson, L., Rimm, E., Hollman, P.C., de Vries, J.H. and Katan, M.B. (2002) Flavonol and Flavone Intakes in US Health Professionals. Journal of the American Dietetic Association, 102, 1414-1420. http://dx.doi.org/10.1016/S0002-8223(02)90314-7

[2] Ross, J.A. and Kasum, C.M. (2002) Dietary Flavonoids: Bioavailability, Metabolic Effects, and Safety. Annual Review of Nutrition, 22, 19-34. http://dx.doi.org/10.1146/annurev.nutr.22.111401.144957

[3] Shih, H., Pickwell, G.V. and Quattrochi, L.C. (2000) Differential Effects of Flavonoid Compounds on Tumor Promoter-Induced Activation of the Human CYP1A2 Enhancer. Archives of Biochemistry and Biophysics, 373, 287-294. http://dx.doi.org/10.1006/abbi.1999.1550

[4] Ferraresi, R., Troiano, L., Roat, E., Lugli, E., Nemes, E., Nasi, M., Pinti, M., Fernandez, M.I., Cooper, E.L. and Cossarizza, A. (2005) Essential Requirement of Reduced Glutathione (GSH) for the Anti-Oxidant Effect of the Flavonoid Quercetin. Free Radical Research, 39, 1249-1258. http://dx.doi.org/10.1080/10715760500306935

[5] Markham, K.R. (1989) Flavones, Flavonols and Their Glycosides. Methods in Plant Biochemistry, 1, 197-235. http://dx.doi.org/10.1016/B978-0-12-461011-8.50012-3

[6] Gugler, R., Leschik, M. and Dengler, H.J. (1975) Disposition of Quercetin in Man after Single Oral and Intravenous Doses. European Journal of Clinical Pharmacology, 9, 229-234. http://dx.doi.org/10.1007/BF00614022

[7] Walle, T., Walle, U.K. and Halushka, P.V. (2001) Carbon Dioxide Is the Major Metabolite of Quercetin in Humans. Journal of Nutrition, 131, 2648-2652.

[8] Boots, A.W., Haenen, G.R. and Bast, A. (2008) Health Effects of Quercetin: From Antioxidant to Nutraceutical. European Journal of Pharmacology, 585, 325-337. http://dx.doi.org/10.1016/j.ejphar.2008.03.008 
[9] Manach, C., Williamson, G., Morand, C., Scalbert, A. and Remesy, C. (2005) Bioavailability and Bioefficacy of Polyphenols in Humans. Review of 97 Bioavailability Studies. The American Journal of Clinical Nutrition, 81, 230S-242S.

[10] de Souza, R.F. and De Giovani, W.F. (2004) Antioxidant Properties of Complexes of Flavonoids with Metal Ions. Redox Report, 9, 97-104. http://dx.doi.org/10.1179/135100004225003897

[11] Heijnen, C.G., Haenen, G.R.M.M., Oostveen, R.M., Stalpers, E.M. and Bast, A. (2002) Protection of Flavonoids against Lipid Peroxidation: The Structure Activity Relationship Revisited. Free Radical Research, 36, 575-581. http://dx.doi.org/10.1080/10715760290025951

[12] Hanasaki, Y., Ogawa, S. and Fukui, S. (1994) The Correlation between Active Oxygens Scavenging and Antioxidative Effects of Flavonoids. Free Radical Biology \& Medicine, 16, 845-850. http://dx.doi.org/10.1016/0891-5849(94)90202-X

[13] Cushnie, T.P. and Lamb, A.J. (2005) Antimicrobial Activity of Flavonoids. International Journal of Antimicrobial Agents, 26, 343-356. http://dx.doi.org/10.1016/j.ijantimicag.2005.09.002

[14] van Acker, S.A., Tromp, M.N., Haenen, G.R.M.M., van der Vijgh, W.J. and Bast, A. (1995) Flavonoids as Scavengers of Nitric Oxide Radical. Biochemical and Biophysical Research Communications, 214, 755-759. http://dx.doi.org/10.1006/bbrc.1995.2350

[15] Haenen, G.R.M.M. and Bast, A. (1999) Nitric Oxide Radical Scavenging of Flavonoids. Methods in Enzymology, 301, 490-503. http://dx.doi.org/10.1016/S0076-6879(99)01112-X

[16] Haenen, G.R.M.M., Paquay, J.B., Korthouwer, R.E. and Bast, A. (1997) Peroxynitrite Scavenging by Flavonoids. Biochemical and Biophysical Research Communications, 236, 591-593. http://dx.doi.org/10.1006/bbrc.1997.7016

[17] Heijnen, C.G., Haenen, G.R.M.M., van Acker, F.A., van der Vijgh, W.J. and Bast, A. (2001) Flavonoids as Peroxynitrite Scavengers: The Role of the Hydroxyl Groups. Toxicology in Vitro, 15, 3-6. http://dx.doi.org/10.1016/S0887-2333(00)00053-9

[18] Hollman, P.C.H. and Katan, M.B. (1997) Absorption, Metabolism and Health Effects of Dietary Flavonoids in Man. Biomedicine \& Pharmacotherapy, 51, 305-310. http://dx.doi.org/10.1016/S0753-3322(97)88045-6

[19] Sakanashi, Y., Oyama, K., Matsui, H., Oyama, T.B., Oyama, T.M., Nishimura, Y., Sakai, H. and Oyama, Y. (2008) Possible Use of Quercetin, an Antioxidant, for Protection of Cells Suffering from Overload of Intracellular $\mathrm{Ca}^{2+}: \mathrm{A}^{-}$ Model Experiment. Life Sciences, 83, 164-169. http://dx.doi.org/10.1016/j.lfs.2008.05.009

[20] Ansari, M.A., Hafiz, M.A., Joshi, G., Opii, W.O. and Butterfield, D.A. (2009) Protective Effect of Quercetin in Primary Neurons against A $\beta$ (1-42): Relevance to Alzheimer's Disease. The Journal of Nutritional Biochemistry, 20, 269275. http://dx.doi.org/10.1016/j.jnutbio.2008.03.002

[21] Balazs, L. and Leon, M. (1994) Evidence of an Oxidative Challenge in the Alzheimer's Brain. Neurochemical Research, 19, 1131-1137. http://dx.doi.org/10.1007/BF00965146

[22] Galati, G., Moridani, M.Y., Chan, T.S. and O’Brien, P.J. (2001) Peroxidative Metabolism of Apigenin and Naringenin versus Luteolin and Quercetin: Glutathione Oxidation and Conjugation. Free Radical Biology \& Medicine, 30, 370382. http://dx.doi.org/10.1016/S0891-5849(00)00481-0

[23] Hollman, P.C. and Katan, M.B. (1999) Dietary Flavonoids: Intake, Health Effects and Bioavailability. Food and Chemical Toxicology, 37, 937-942. http://dx.doi.org/10.1016/S0278-6915(99)00079-4

[24] Skibola, C.F. and Smith, M.T. (2000) Potential Health Impacts of Excessive Flavonoid Intake. Free Radical Biology \& Medicine, 29, 375-383. http://dx.doi.org/10.1016/S0891-5849(00)00304-X

[25] Yang, C.S. and Wang, Z.-Y. (1993) Tea and Cancer. Journal of the National Cancer Institute, 85, 1038-1049. http://dx.doi.org/10.1093/jnci/85.13.1038

[26] IARC (International Agency for Research on Cancer) (1988) Monographs on the Evaluation of Carcinogenic Risks to Humans. Vol. 44: Alcohol Drinking, IARC, Lyon.

[27] Longnecker, M.P., Orza, M.J., Adams, M.E., Vioque, J. and Chalmers, T.-C. (1990) A Meta-Analysis of Alcoholic Beverage Consumption in Relation to Risk of Colorectal Cancer. Cancer Causes \& Control, 1, 59-68. http://dx.doi.org/10.1007/BF00053184

[28] Dorant, E. (1994) Onion and Leek Consumption, Garlic Supplement Use and the Incidence of Cancer. PhD Thesis, University of Limburg, Maastricht.

[29] Tan, W.F., Lin, L.P., Li, M.H., Zhang, Y.X., Tong, Y.G., et al. (2003) Quercetin, a Dietary Derived Flavonoid, Possesses Antiangiogenic Potential. European Journal of Pharmacology, 459, 255-262. http://dx.doi.org/10.1016/S0014-2999(02)02848-0

[30] Noori-Daloii, M.R., Momeny, M., Yousefi, M., Shirazi, F.G., Yaseri, M., et al. (2011) Multifaceted Preventive Effects of Single Agent Quercetin on a Human Prostate Adenocarcinoma Cell Line (PC-3): Implications for Nutritional Transcriptomics and Multi-Target Therapy. Medical Oncology, 28, 1395-1404. 
http://dx.doi.org/10.1007/s12032-010-9603-3

[31] Ranelletti, F.O., Ricci, R., Larocca, L.M., Maggiano, N., Capelli, A., et al. (1992) Growth-Inhibitory Effect of Quercetin and Presence of Type-II Estrogenbinding Sites in Human Colon-Cancer Cell Lines and Primary Colorectal Tumors. International Journal of Cancer, 50, 486-492. http://dx.doi.org/10.1002/ijc.2910500326

[32] Caltagirone, S., Ranelletti, F.O., Rinelli, A., Maggiano, N., Colasante, A., et al. (1997) Interaction with Type II Estrogen Binding Sites and Antiproliferative Activity of Tamoxifen and Quercetin in Human Non-Small-Cell Lung Cancer. American Journal of Respiratory Cell and Molecular Biology, 17, 51-59. http://dx.doi.org/10.1165/ajrcmb.17.1.2728

[33] Tanako, K., Ono, T. and Umeda, M. (1987) Pleiotropic Effects of Quercetin on the Transformation of Balb 3T3 Cells. Japanese Journal of Cancer Research, 78, 819-825.

[34] Mukhtar, H., Das, M., Khan, W.A., Wang, Z.Y., Bik, D.P. and Bickers, D.R. (1988) Exceptional Activity of Tannic Acid among Naturally Occurring Plant Phenols in Protecting against 7,12-Dimethylbenz(a)anthracene-, benzo(a)pyrene, 3-Methylcholanthrene-, and N-Methylnitroso Urea-Induced Skin Tumorigenesis in Mice. Cancer Research, 48, 23612365.

[35] Aizu, E., Nakadata, T. and Yamamoto, S. (1986) Inhibition of 12-O-tetradecaaoylphorbol-13-acetate Mediated Epidermal Ornithine Decarboxylase Induction and Skin Tumor Promotion by New Lipoxygenase Inhibitors Lacking Protein Kinase C Inhibitory Effects. Carcinogenesis, 7, 1809-1812. http://dx.doi.org/10.1093/carcin/7.11.1809

[36] Notarnicola, M., Messa, C., Orlando, A., Bifulco, M., Laezza, C., Gazzerro, P. and Caruso, M.G. (2008) Estrogenic Induction of Cannabinoid CB1 Receptor in Human Colon Cancer Cell Lines. Scandinavian Journal of Gastroenterology, 43, 66-72. http://dx.doi.org/10.1080/00365520701559011

[37] Di Leo, A., Messa, C., Cavallini, A. and Linsalata, M. (2001) Estrogens and Colorectal Cancer. Current Drug Targets. Immune Endocrine \& Metabolic Disorders, 1, 1-12. http://dx.doi.org/10.2174/1568008013341749

[38] De Petrocellis, L., Melck, D., Palmisano, A., Bisogno, T., Laezza, C., Bifulco, M. and Di Marzo, V. (1998) The Endogenous Cannabinoid Anandamide Inhibits Human Breast Cancer Cell Proliferation. Proceedings of the National Academy of Sciences of the United States of America, 95, 8375-8380. http://dx.doi.org/10.1073/pnas.95.14.8375

[39] Bremner, P. and Heinrich, M. (2002) Natural Products as Targeted Modulators of the Nuclear Factor-KappaB Pathway. Journal of Pharmacy and Pharmacology, 54, 453-472. http://dx.doi.org/10.1211/0022357021778637

[40] Nam, N.H. (2006) Naturally Occurring NF-KappaB Inhibitors. Mini-Reviews in Medicinal Chemistry, 6, 945-951. http://dx.doi.org/10.2174/138955706777934937

[41] Min, Y.D., Choi, C.H., Bark, H., et al. (2007) Quercetin Inhibits Expression of Inflammatory Cytokines through Attenuation of NF-KappaB and p38 MAPK in HMC-1 Human Mast Cell Line. Inflammation Research, 56, 210-215. http://dx.doi.org/10.1007/s00011-007-6172-9

[42] Hishikawa, K. and Nakaki, T. (2001) NF-KappaB as a Therapeutic Drug Target. Nihon Yakurigaku Zasshi, 118, 197202. (In Japanese) http://dx.doi.org/10.1254/fpj.118.197

[43] Schneider, G. and Krämer, O.H. (2011) NF $\kappa$ B/p53 Crosstalk-A Promising New Therapeutic Target. Biochimica et Biophysica Acta, 1815, 90-103. http://dx.doi.org/10.1016/j.bbcan.2010.10.003

[44] Perkins, N.D. (2007) Integrating Cell Signaling Pathways with NF- $\kappa$ B and IKK Function. Nature Reviews Molecular Cell Biology, 8, 49-62.

[45] Kim, Y.H. and Lee, Y.J. (2007) TRAIL Apoptosis Is Enhanced by Quercetin through Akt Dephosphorylation. Journal of Cellular Biochemistry, 100, 998-1009. http://dx.doi.org/10.1002/jcb.21098

[46] Wang, K., Liu, R., Li, J., et al. (2011) Quercetin Induces Protective Autophagy in Gastric Cancer Cells: Involvement of Akt-mTOR and Hypoxia-Induced Factor $1 \alpha$-Mediated Signaling. Autophagy, 7, 966-978. http://dx.doi.org/10.4161/auto.7.9.15863

[47] Gupta, S.C., Kim, J.H., Prasad, S. and Aggarwal, B.B. (2010) Regulation of Survival, Proliferation, Invasion, Angiogenesis, and Metastasis of Tumor Cells through Modulation of Inflammatory Pathways by Nutraceuticals. Cancer and Metastasis Reviews, 29, 405-434. http://dx.doi.org/10.1007/s10555-010-9235-2

[48] Vargas, A.J., Sittadjody, S., Thangasamy, T., Mendoza, E.E., Limesand, K.H. and Burd, R. (2011) Exploiting Tyrosinase Expression and Activity in Melanocytic Tumors: Quercetin and the Central Role of p53. Integrative Cancer Therapies, 10, 328-340. http://dx.doi.org/10.1177/1534735410391661

[49] Kong, D., Zhang, Y., Yamori, T., Duan, H. and Jin, M. (2011) Inhibitory Activity of Flavonoids against Class I Phosphatidylinositol 3-Kinase Isoforms. Molecules, 16, 5159-5167. http://dx.doi.org/10.3390/molecules16065159

[50] Hou, D.X. and Kumamoto, T. (2010) Flavonoids as Protein Kinase Inhibitors for Cancer Chemoprevention: Direct Binding and Molecular Modeling. Antioxidants \& Redox Signaling, 13, 691-719. http://dx.doi.org/10.1089/ars.2009.2816

[51] Hwang, M.K., Song, N.R., Kang, N.J., Lee, K.W. and Lee, H.J. (2009) Activation of Phosphatidylinositol 3-Kinase Is 
Required for Tumor Necrosis Factor-Alpha-Induced Upregulation of Matrix Metalloproteinase-9: Its Direct Inhibition by Quercetin. The International Journal of Biochemistry \& Cell Biology, 41, 1592-1600. http://dx.doi.org/10.1016/j.biocel.2009.01.014

[52] Chirumbolo, S. (2010) The Role of Quercetin, Flavonols and Flavones in Modulating Inflammatory Cell Function. Inflamm Allergy—Drug Targets, 9, 263-285. http://dx.doi.org/10.2174/187152810793358741

[53] Kim, S.H., Yeo, G.S., Lim, Y.S., Kang, C.D., Kim, C.M. and Chung, B.S. (1998) Suppression of Multidrug Resistance via Inhibition of Heat Shock Factor by Quercetin in MDR Cells. Experimental \& Molecular Medicine, 30, 87-92. http://dx.doi.org/10.1038/emm.1998.13

[54] Oh, S.J., Kim, O., Lee, J.S., et al. (2010) Inhibition of Angiogenesis by Quercetin in Tamoxifen-Resistant Breast Cancer Cells. Food and Chemical Toxicology, 48, 3227-3234. http://dx.doi.org/10.1016/j.fct.2010.08.028

[55] Shen, J., Zhang, W., Wu, J. and Zhu, Y. (2008) The Synergistic Reversal Effect of Multidrug Resistance by Quercetin and Hyperthermia in Doxorubicin-Resistant Human Myelogenous Leukemia Cells. International Journal of Hyperthermia, 24, 151-159. http://dx.doi.org/10.1080/02656730701843109

[56] Sliutz, G., Karlseder, J., Tempfer, C., Orel, L., Holzer, G. and Simon, M.M. (1996) Drug Resistance against Gemcitabine and Topotecan Mediated by Constitutive hsp70 Overexpression in Vitro: Implication of Quercetin as Sensitiser in Chemotherapy. British Journal of Cancer, 74, 172-177. http://dx.doi.org/10.1038/bjc.1996.334

[57] Thangasamy, T., Sittadjody, S., Mitchell, G.C., Mendoza, E.E., Radhakrishnan, V.M., Limesand, K.H. and Burd, R. (2010) Quercetin Abrogates Chemoresistance in Melanoma Cells by Modulating 4Np73. BMC Cancer, 10, 282. http://dx.doi.org/10.1186/1471-2407-10-282

[58] Wang, H., Tao, L., Qi, K., Zhang, H., Feng, D., Wei, W., Kong, H., Chen, T. and Lin, Q. (2015) Quercetin Reverses Tamoxifen Resistance in Breast Cancer Cells. Journal of BUON, 20, 707-713.

[59] Scambia, G., Raneletti, F.O., Panici, P.B., et al. (1992) Inhibitory Effect of Quercetin on Primary Ovarian and Endometrial Cancers and Synergistic Activity with Cis-Diamminedichloroplatinum(II). Gynecologic Oncology, 45, 13-19. http://dx.doi.org/10.1016/0090-8258(92)90484-Z

[60] Scambia, G., Raneletti, F.O., Panici, P.B., Bonanno, G., De Vincenzo, R., Piantelli, M. and Mancuso, S. (1990) Synergistic Antiproliferative Activity of Quercetin and Cisplatin on Ovarian Cancer Cell Growth. Anticancer Drugs, 1, 4548. http://dx.doi.org/10.1097/00001813-199010000-00008

[61] Akbas, S.H., Timur, M. and Ozben, T. (2005) The Effect of Quercetin on Topotecan Cytotoxicity in MCF-7 and MDA-MB 231 Human Breast Cancer Cells. Journal of Surgical Research, 125, 49-55. http://dx.doi.org/10.1016/j.jss.2004.11.011

[62] Borska, S., Gebarowska, E., Wysocka, T., et al. (2004) The Effects of Quercetin vs Cisplatin on Proliferation and the Apoptotic Process in A549 and SW1271 Cell Lines in in Vitro Conditions. Folia Morphologica, 63, 103-105.

[63] Du, G., Lin, H., Yang, Y., et al. (2010) Dietary Quercetin Combining Intratumoral Doxorubicin Injection Synergistically Induces Rejection of Established Breast Cancer in Mice. International Immunopharmacology, 10, 819-826. http://dx.doi.org/10.1016/j.intimp.2010.04.018

[64] Jakubowicz-Gil, J., Paduch, R., Piersiak, T., et al. (2005) The Effect of Quercetin on Pro-Apoptotic Activity of Cisplatin in HeLa Cells. Biochemical Pharmacology, 69, 1343-1350. http://dx.doi.org/10.1016/j.bcp.2005.01.022

[65] Li, W., Shen, F. and Weber, G. (1999) Ribavirin and Quercetin Synergistically Downregulate Signal Transduction and Are Cytotoxic in Human Ovarian Carcinoma Cells. Oncology Research, 11, 243-247.

[66] Piantelli, M., Tatone, D., Castrilli, G., et al. (2001) Quercetin and Tamoxifen Sensitize Human Melanoma Cells to Hyperthermia. Melanoma Research, 11, 469-476. http://dx.doi.org/10.1097/00008390-200110000-00005

[67] Scambia, G., Ranelletti, F.O., Panici, P.B., et al. (1991) Quercetin Inhibits the Growth of a Multidrug-Resistant Estrogen-Receptor Negative MCF-7 Human Breast-Cancer Cell Line Expressing Type II Estrogen Binding Sites. Cancer Chemotherapy and Pharmacology, 28, 255-258. http://dx.doi.org/10.1007/BF00685531

[68] Scambia, G., Ranelletti, F.O., Panici, P.B., et al. (1994) Quercetin Potentiates the Effect of Adriamycin in a MultidrugResistant MCF-7 Human Breast-Cancer Cell Line: P-Glycoprotein as a Possible Target. Cancer Chemotherapy and Pharmacology, 34, 459-464. http://dx.doi.org/10.1007/BF00685655

[69] Sharma, H., Sen, S. and Singh, N. (2005) Molecular Pathways in the Chemosensitization of Cisplatin by Quercetin in Human Head and Neck Cancer. Cancer Biology \& Therapy, 4, 949-955. http://dx.doi.org/10.4161/cbt.4.9.1908

[70] Shen, F. and Weber, G. (1997) Synergistic Action of Quercetin and Genistein in Human Ovarian Carcinoma Cells. Oncology Research, 9, 597-602.

[71] Staedler, D., Idrizi, E., Kenzaoui, B.H. and Juillerat-Jeanneret, L. (2011) Drug Combinations with Quercetin: Doxorubicin plus Quercetin in Human Breast Cancer Cells. Cancer Chemotherapy and Pharmacology, 68, 1161-1172.

http://dx.doi.org/10.1007/s00280-011-1596-x 
[72] Václavíková, R., Kondrová, E., Ehrlichová, M., et al. (2008) The Effect of Flavonoid Derivatives on Doxorubicin Transport and Metabolism. Bioorganic \& Medicinal Chemistry, 16, 2034-2042. http://dx.doi.org/10.1016/j.bmc.2007.10.093

[73] Yeh, Y.A., Herenyiova, M. and Weber, G. (1995) Quercetin: Synergistic Action with Carboxyamidotriazole in Human Breast Carcinoma Cells. Life Sciences, 57, 1285-1292. http://dx.doi.org/10.1016/0024-3205(95)02085-W

[74] Baek, S.H., Lee, U.Y., Park, E.M., Han, M.Y., Lee, Y.S. and Park, Y.M. (2001) Role of Protein Kinase C $\delta$ in Transmitting Hypoxia Signal to HSF and HIF-1. Journal of Cellular Physiology, 188, 223-235. http://dx.doi.org/10.1002/jcp.1117

[75] Lin, C.W., Hou, W.C., Shen, S.C., Juan, S.H., Ko, C.H., Wang, L.M. and Chen, Y.C. (2008) Quercetin Inhibition of Tumor Invasion via Suppressing PKC delta/ERK/AP-1-Dependent Matrix Metalloproteinase-9 Activation in Breast Carcinoma Cells. Carcinogenesis, 29, 1807-1815. http://dx.doi.org/10.1093/carcin/bgn162

[76] Maurya, A.K. and Vinayak, M. (2015) Modulation of PKC Signaling and Induction of Apoptosis through Suppression of Reactive Oxygen Species and Tumor Necrosis Factor Receptor 1 (TNFR1): Key Role of Quercetin in Cancer Prevention. Tumor Biology, 36, 8913-8924. http://dx.doi.org/10.1007/s13277-015-3634-5

[77] Hu, C.T., Wu, J.R., Cheng, C.C., Wang, S., Wang, H.T., Lee, M.C., et al. (2011) Reactive Oxygen Species-Mediated PKC and Integrin Signaling Promotes Tumor Progression of Human Hepatoma HepG2. Clinical \& Experimental Metastasis, 28, 851-863. http://dx.doi.org/10.1007/s10585-011-9416-6

[78] Aspects, D., Giorgi, C., Agnoletto, C., Baldini, C., Bononi, A., Bonora, M., et al. (2010) Redox Control of Protein Kinase C: Cell- and Disease-Specific Aspects. Antioxidants \& Redox Signaling, 13, 1051-1085. http://dx.doi.org/10.1089/ars.2009.2825

[79] Gopalakrishna, R. and Gundimeda, U. (2002) Antioxidant Regulation of Protein Kinase C in Cancer Prevention. Journal of Nutrition, 132, 3819-3823.

[80] Mukherjee, A. and Khuda-Bukhsh, A.R. (2015) Quercetin Down-Regulates IL-6/STAT-3 Signals to Induce Mitochondrial-Mediated Apoptosis in a Non-Small-Cell Lung Cancer Cell Line, A549. Journal of Pharmacopuncture, 18, 19-26. http://dx.doi.org/10.3831/KPI.2015.18.002

[81] Chen, C., Zhou, J. and Ji, C. (2010) Quercetin: A Potential Drug to Reverse Multidrug Resistance. Life Sciences, 87, 333-338. http://dx.doi.org/10.1016/j.lfs.2010.07.004

[82] Larocca, L.M., Teofili, L., Sica, S., Piantelli, M., Maggiano, N., Leone, G. and Ranelletti, F.O. (1995) Quercetin Inhibits the Growth of Leukemic Progenitors and Induces the Expression of Transforming Growth Factor-Beta 1 in These Cells. Blood, 85, 3654-3661.

[83] Keller, J.R., Jacobsen, S.E.W., Dubois, C.M., Hestdal, K. and Ruscetti, F.W. (1992) Trasforming Growth Factor Beta: A Bidiretional Regulator of Hematopoietic Cell Growth. The International Journal of Cell Cloning, 10, 2-11. http://dx.doi.org/10.1002/stem.5530100103

[84] Bonewald, L.F. (1992) Can Transforming Growth Factor Beta Be Useful as a Protective Agent for Pluripotent Hematopoietic Progenitor Cells? Experimental Hematology, 20, 1249-1251.

[85] Jacobsen, S.E.W., Ruscetti, F.W., Roberts, A.B. and Keller, J.R. (1993) TGFp Is a Bidirectional Modulator of Cytokine Receptor Expression on Murine Bone Marrow Cells. Differential Effects of TGF-PI and TGFp3. The Journal of Immunology, 151, 4534-4544.

[86] Aglietta, M., Stacchini, A., Severino, A., Sanavio, F., Ferrando, M.L. and Piacibello, W. (1989) Interaction of Transforming Growth Factor-Beta 1 with Hematopoietic Growth Factors in the Regulation of Human Normal and Leukemic Myelopoiesis. Experimental Hematology, 17, 296-299.

[87] Jacobsen, S.E.W., Keller, J.R., Ruscetti, F.W., Kondaiah, P., Roberts, A.B. and Falk, L.A. (1991) Bidirectional Effects of TGF-P on Colony-Stimulating Factor Induced Human Myelopoiesis in Vitro: Differential Effects of Distinct TGF-P Isoforms. Blood, 78, 2239-2247.

[88] Hatzfeld, J., Li, M.L., Brown, E.L., Sookdeo, H., Levesque, J.P., O’Toole, T., Gurney, C., Clark, S.C. and Hatzfeld, A. (1991) Release of Early Hematopoietic Progenitors from Quiescence by Antisense Transforming Growth Factor p1 or Rb Oligonucleotides. The Journal of Experimental Medicine, 174, 925-929. http://dx.doi.org/10.1084/jem.174.4.925

[89] Busuker, I., Neddermann, K.M., Petty, B.A., Schacter, B., Spitalny, G.L., Tepper, M.A. and Pasternak, R.D. (1992) In Vivo Regulation of Hemopoiesis by Transforming Growth Factor p 1. Stimulation of GM-CSF- and M-CSF-Dependent Murine Bone Marrow Precursors. Experimental Hematology, 20, 431-435.

[90] Scambia, G., Benedetti, P., Ranelletti, F.O., Ferrandina, G., De Vincenzo, R., Piantelli, M., Masciullo, V., Bonanno, G., Kola, G. and Mancuso, S. (1994) Quercetin Enhances Transforming Growth Factor P1 Secretion by Human Ovarian Cancer Cells. International Journal of Cancer, 57, 211-215. http://dx.doi.org/10.1002/ijc.2910570214

[91] Chang, W.W., Hu, F.W., Yu, C.C., et al. (2013) Quercetin in Elimination of Tumor Initiating Stem-Like and Mesenchymal Transformation Property in Head and Neck Cancer. Head \& Neck, 35, 413-419. 
http://dx.doi.org/10.1002/hed.22982

[92] Wei, L., Liu, T.T., Wang, H.H., et al. (2011) HSP27 Participates in the Maintenance of Breast Cancer Stem Cells through Regulation of Epithelial-Mesenchymal Transition and Nuclear Factor- $\kappa$ B. Breast Cancer Research, 13, R101. http://dx.doi.org/10.1186/bcr3042

[93] Chen, S.F., Nieh, S., Jao, S.W., et al. (2012) Quercetin Suppresses Drug-Resistance Spheres via the p38 MAPK-Hsp27 Apoptotic Pathway in Oral Cancer Cells. PLoS ONE, 7, e49275. http://dx.doi.org/10.1371/journal.pone.0049275

[94] Adikrisna, R., Tanaka, S., Muramatsu, S., et al. (2012) Identification of Pancreatic Cancer Stem Cells and Selective Toxicity of Chemotherapeutic Agents. Gastraoenterology, 143, 234-245. http://dx.doi.org/10.1053/j.gastro.2012.03.054

[95] Zhou, W., Kallifatidis, G., Bauman, B., et al. (2010) Dietary Polyphenol Quercetin Targets Pancreatic Cancer Stem Cells. International Journal of Oncology, 37, 551-561.

[96] Virgili, F., Acconcia, F., Ambra, R., Rinna, A., Totta, P. and Marino, M. (2004) Nutritional Flavonoids Modulate Estrogen Receptor Alpha Signaling. IUBMB Life, 56, 145-151. http://dx.doi.org/10.1080/15216540410001685083

[97] Ruiz, P.A. and Haller, D. (2006) Functional Diversity of Flavonoids in the Inhibition of the Proinflammatory NF- $\kappa$ B, IRF, and Akt Signaling Pathways in Murine Intestinal Epithelial Cells. Journal of Nutrition, 136, 664-671.

[98] Muthian, G. and Bright, J.J. (2004) Quercetin, a Flavonoid Phytoestrogen, Ameliorates Experimental Allergic Encephalomyelitis by Blocking IL-12 Signaling through JAK-STAT Pathway in T Lymphocyte. Journal of Clinical Immunology, 24, 542-552. http://dx.doi.org/10.1023/B:JOCI.0000040925.55682.a5

[99] Wang, Z., Zhang, Y., Banerjee, S., Li, Y. and Sarkar, F.H. (2006) Inhibition of Nuclear Factor KappaB Activity by Genistein Is Mediated via Notch-1 Signaling Pathway in Pancreatic Cancer Cells. International Journal of Cancer, 118, 1930-1936. http://dx.doi.org/10.1002/ijc.21589

[100] Amado, N.G., Fonseca, B.F., Cerqueira, D.M., Neto, V.M. and Abreu, J.G. (2011) Flavonoids: Potential Wnt/BetaCatenin Signaling Modulators in Cancer. Life Sciences, 89, 545-554. http://dx.doi.org/10.1016/j.lfs.2011.05.003

[101] Bhat, F.A., Sharmila, G., Balakrishnan, S., Arunkumar, R., Elumalai, P., Suganya, S., Raja Singh, P., Srinivasan, N. and Arunakaran, J. (2014) Quercetin Reverses EGF-Induced Epithelial to Mesenchymal Transition and Invasiveness in Prostate Cancer (PC-3) Cell Line via EGFR/PI3K/Akt Pathway. The Journal of Nutritional Biochemistry, 25, 11321139. http://dx.doi.org/10.1016/j.jnutbio.2014.06.008

[102] Chen, W., Wang, X., Zhuang, J., Zhang, L. and Lin, Y. (2007) Induction of Death Receptor 5 and Suppression of Survivin Contribute to Sensitization of TRAIL-Induced Cytotoxicity by Quercetin in Non-Small Cell Lung Cancer Cells. Carcinogenesis, 28, 2114-2121. http://dx.doi.org/10.1093/carcin/bgm133

[103] Jung, M., Bu, S.Y., Tak, K.H., Park, J.E. and Kim, E. (2013) Anticarcinogenic Effect of Quercetin by Inhibition of Insulin-Like Growth Factor (IGF)-1 Signaling in Mouse Skin Cancer. Nutrition Research and Practice, 7, 439-445. http://dx.doi.org/10.4162/nrp.2013.7.6.439

[104] Vidya Priyadarsini, R., Senthil Murugan, R., Maitreyi, S., Ramalingam, K., Karunagaran, D. and Nagini, S. (2010) The Flavonoid Quercetin Induces Cell Cycle Arrest and Mitochondria-Mediated Apoptosis in Human Cervical Cancer (HeLa) Cells through p53 Induction and NF- $\kappa$ B Inhibition. European Journal of Pharmacology, 649, 84-91. http://dx.doi.org/10.1016/j.ejphar.2010.09.020

[105] Mu, C., Jia, P., Yan, Z., Liu, X., Li, X. and Liu, H. (2007) Quercetin Induces Cell Cycle G1 Arrest through Elevating Cdk Inhibitors p21 and p27 in Human Hepatoma Cell Line (HepG2). Methods and Findings in Experimental and Clinical Pharmacology, 29, 179-183. http://dx.doi.org/10.1358/mf.2007.29.3.1092095

[106] Jung, J.H., Lee, J.O., Kim, J.H., et al. (2010) Quercetin Suppresses HeLa Cell Viability via AMPK-Induced HSP70 and EGFR Down-Regulation. Journal of Cellular Physiology, 223, 408-414. http://dx.doi.org/10.1002/jcp.22049

[107] Sibata, C.H., Colussi, V.C., Oleinick, N.L. and Kinsella, T.J. (2000) Photodynamic Therapy: A New Concept in Medical Treatment. Brazilian Journal of Medical and Biological Research, 33, 869-880. http://dx.doi.org/10.1590/S0100-879X2000000800002

[108] Agostinis, P., Berg, K., Cengel, K.A., Foster, T.H., Girotti, A.W., Gollnick, S.O., Hahn, S.M., Hamblin, M.R., Juzeniene, A., Kessel, D., Korbelik, M., Moan, J., Mroz, P., Nowis, D., Piette, J., Wilson, B.C. and Golab, J. (2011) Photodynamic Therapy of Cancer: An Update. CA: A Cancer Journal for Clinicians, 61, 250-281. http://dx.doi.org/10.3322/caac.20114

[109] Dougherty, T.J. (2002) An Update on Photodynamic Therapy Applications. Journal of Clinical Laser Medicine \& Surgery, 20, 3-7. http://dx.doi.org/10.1089/104454702753474931

[110] Kübler, A.C. (2005) Photodynamic Therapy. Medical Laser Application, 20, 37-45. http://dx.doi.org/10.1016/j.mla.2005.02.001

[111] Ferreira, S.D.R.M., Tedesco, A.C., Sousa, G., Zângaro, R.A., Silva, N.S., Pacheco, M.T.T. and Pacheco-Soares, C. 
(2004) Analysis of Mitochondria, Endoplasmic Reticulum and Actin Filaments after PDT with AIPcS4. Lasers in Medical Science, 18, 207-212. http://dx.doi.org/10.1007/s10103-003-0282-6

[112] Machado, A.H.A., Moraes, K.C.M., Pacheco-Soares, C., Beltrame Jr., M. and da Silva, N.S. (2010) Cellular Changes after Photodynamic Therapy on HEp-2 Cells Using the New ZnPcBr8 Phthalocyanine. Photomedicine and Laser Surgery, 28, S143-S149. http://dx.doi.org/10.1089/pho.2009.2561

[113] Rodrigues, R.P., Tini, I.R.P., Soares, C.P. and Silva, N.S. (2014) Effect of Photodynamic Therapy Supplemented with Quercetin in HEp-2 Cells. Cell Biology International, 38, 716-722. http://dx.doi.org/10.1002/cbin.10251

[114] Rodewald, H.R., Dessing, M., Dvorak, A.M. and Galli, S.J. (1996) Identification of a Committed Precursor for the Mast Cell Lineage. Science, 271, 818-822. http://dx.doi.org/10.1126/science.271.5250.818

[115] Chen, C.C., Grimbaldeston, M.A., Tsai, M., Weissman, I.L. and Galli, S.J. (2005) Identification of Mast Cell Progenitors in Adult Mice. Proceedings of the National Academy of Sciences of the United States of America, 102, 1140811413. http://dx.doi.org/10.1073/pnas.0504197102

[116] Galli, S.J. (1993) New Concepts about the Mast Cell. The New England Journal of Medicine, 328, 257-265. http://dx.doi.org/10.1056/NEJM199301283280408

[117] Siraganian, R.P. (2003) Mast Cell Signal Transduction from the High-Affinity IgE Receptor. Current Opinion in Immunology, 15, 639-646. http://dx.doi.org/10.1016/j.coi.2003.09.010

[118] Blank, U. and Rivera, J. (2004) The Ins and Outs of IgE-Dependent Mast-Cell Exocytosis. Trends in Immunology, 25, 266-273. http://dx.doi.org/10.1016/j.it.2004.03.005

[119] Kraft, S., Rana, S., Jouvin, M.H. and Kinet, J.P. (2004) The Role of the FceRI Beta-Chain in Allergic Diseases. International Archives of Allergy and Immunology, 135, 62-72. http://dx.doi.org/10.1159/000080231

[120] Castells, M. (2006) Mast Cell Mediators in Allergic Inflammation and Mastocytosis. Immunology and Allergy Clinics of North America, 26, 465-485. http://dx.doi.org/10.1016/j.iac.2006.05.005

[121] Galli, S.J. and Tsai, M. (2010) Mast Cells in Allergy and Infection: Versatile Effector and Regulatory Cells in Innate and Adaptive Immunity. European Journal of Immunology, 40, 1843-1851. http://dx.doi.org/10.1002/eji.201040559

[122] Mekori, Y.A. and Metcalfe, D.D. (2000) Mast Cells in Innate Immunity. Immunological Reviews, 173, $131-140$. http://dx.doi.org/10.1034/j.1600-065X.2000.917305.X

[123] Wedemeyer, J., Tsai, M. and Galli, S.J. (2000) Roles of Mast Cells and Basophils in Innate and Acquired Immunity. Current Opinion in Immunology, 12, 624-631. http://dx.doi.org/10.1016/S0952-7915(00)00154-0

[124] Theoharides, T.C. and Cochrane, D.E. (2004) Critical Role of Mast Cells in Inflammatory Diseases and the Effect of Acute Stress. Journal of Neuroimmunology, 146, 1-12. http://dx.doi.org/10.1016/j.jneuroim.2003.10.041

[125] Kim, M., Lim, S.J., Kang, S.W., Um, B.H. and Nho, C.W. (2014) Aceriphyllum Rossii Extract and Its Active Compounds, Quercetin and Kaempferol Inhibit IgE-Mediated Mast Cell Activation and Passive Cutaneous Anaphylaxis. Journal of Agricultural and Food Chemistry, 62, 3750-3758. http://dx.doi.org/10.1021/jf405486c

[126] Geoghegan, F., Wong, R.W. and Rabie, A.B. (2010) Inhibitory Effect of Quercetin on Periodontal Pathogens in Vitro. Phytotherapy Research, 24, 817-820.

[127] Li, M. and Xu, Z. (2008) Quercetin in a Lotus Leaves Extract May Be Responsible for Antibacterial Activity. Archives of Pharmacal Research, 31, 640-644. http://dx.doi.org/10.1007/s12272-001-1206-5

[128] Beil, W., Birkholz, C. and Sewing, K.F. (1995) Effects of Flavonoids on Parietal Cell Acid Secretion, Gastric Mucosal Prostaglandin Production and Helicobacter pylori Growth. Arzneimittelforschung, 45, 697-700.

[129] Shin, J.E., Kim, J.M., Bae, E.A., et al. (2005) In Vitro Inhibitory Effect of Flavonoids on Growth, Infection and Vacuolation of Helicobacter pylori. Planta Medica, 71, 197-201. http://dx.doi.org/10.1055/s-2005-837816

[130] González-Segovia, R., Quintanar, J.L., Salinas, E., et al. (2008) Effect of the Flavonoid Quercetin on Inflammation and Lipid Peroxidation Induced by Helicobacter pylori in Gastric Mucosa of Guinea Pig. Journal of Gastroenterology, 43, 441-447. http://dx.doi.org/10.1007/s00535-008-2184-7

[131] Amin, M.U., Khurram, M., Khattak, B. and Khan, J. (2015) Antibiotic Additive and Synergistic Action of Rutin, Morin and Quercetin against Methicillin Resistant Staphylococcus aureus. BMC Complementary and Alternative Medicine, 15, 59. http://dx.doi.org/10.1186/s12906-015-0580-0

[132] Betts, J.W., Sharili, A.S., Phee, L.M. and Wareham, D.W. (2015) In Vitro Activity of Epigallocatechin Gallate and Quercetin Alone and in Combination versus Clinical Isolates of Methicillin-Resistant Staphylococcus aureus. Journal of Natural Products, 78, 2145-2148. http://dx.doi.org/10.1021/acs.jnatprod.5b00471

[133] Kaul, T.N., Middleton Jr., E. and Ogra, P.L. (1985) Antiviral Effect of Flavonoids on Human Viruses. Journal of Medical Virology, 15, 71-79. http://dx.doi.org/10.1002/jmv.1890150110

[134] Vrijsen, R., Everaert, I. and Boeye, A. (1988) Antiviral Activity of Flavones and Potentiation by Ascorbate. Journal of 
General Virology, 68, 1749-1751. http://dx.doi.org/10.1099/0022-1317-69-7-1749

[135] Bachmetov, L., Gal-Tanamy, M., Shapira, A., Vorobeychik, M., Giterman-Galam, T., Sathiyamoorthy, P., GolanGoldhirsh, A., Benhar, I., Tur-Kaspa, R. and Zemel, R. (2012) Suppression of Hepatitis C Virus by the Flavonoid Quercetin Is Mediated by Inhibition of NS3 Protease Activity. Journal of Viral Hepatitis, 19, e81-e8. http://dx.doi.org/10.1111/j.1365-2893.2011.01507.x

[136] Çevik, Ö., Çadırcı, S., Şener, T.E., Tinay, I., Akbal, C., Tavukçu, H.H., Çetinel, S., Kıran, D. and Şener, G. (2013) Quercetin Treatment against Ischemia/Reperfusion Injury in Rat Corpus Cavernosum Tissue: A Role on Apoptosis and Oxidative Stress. Free Radical Research, 47, 683-691. http://dx.doi.org/10.3109/10715762.2013.814912

[137] Lapi, D., Vagnani, S., Pignataro, G., Esposito, E., Paterni, M. and Colantuoni, A. (2012) Protective Effects of Quercetin on Rat Pial Microvascular Changes during Transient Bilateral Common Carotid Artery Occlusion and Reperfusion. Frontiers in Physiology, 3, 32. http://dx.doi.org/10.3389/fphys.2012.00032

[138] Lara-Guzman, O.J., Tabares-Guevara, J.H., Leon-Varela, Y.M., Álvarez, R.M., Roldan, M., Sierra, J.A., LondoñoLondoño, J.A. and Ramirez-Pineda, J.R. (2012) Proatherogenic Macrophage Activities Are Targeted by the Flavonoid Quercetin. Journal of Pharmacology and Experimental Therapeutics, 343, 296-306. http://dx.doi.org/10.1124/jpet.112.196147

[139] Kawai, Y., Nishikawa, T., Shiba, Y., Saito, S., Murota, K., Shibata, N., Kobayashi, M., Kanayama, M., Uchida, K. and Terao, J. (2008) Macrophage as a Target of Querceting Lucuronides in Human Atherosclerotic Arteries: Implication in the Anti-Atherosclerotic Mechanism of Dietary Flavonoids. The Journal of Biological Chemistry, 283, 9424-9434. http://dx.doi.org/10.1074/jbc.M706571200

[140] He, Y., Cao, X., Liu, X., Li, X., Xu, Y., Liu, J. and Shi, J. (2015) Quercetin Reverses Experimental Pulmonary Arterial Hypertension by Modulating the TrkA Pathway. Experimental Cell Research, 339, 122-134. http://dx.doi.org/10.1016/j.yexcr.2015.10.013

[141] Adewole, S.O., Caxton-Martins, E.A. and Ojewole, J.A. (2006) Protective Effect of Quercetin on the Morphology of Pancreatic Beta-Cells of Streptozotocintreated Diabetic Rats. African Journal of Traditional, Complementary and Alternative Medicines, 4, 64-74.

[142] Anjaneyulu, M., Chopra, K. and Kaur, I. (2003) Antidepressant Activity of Quercetin, a Bioflavonoid, in Streptozotocin-Induced Diabetic Mice. Journal of Medicinal Food, 6, 391-395. http://dx.doi.org/10.1089/109662003772519976

[143] Anjaneyulu, M. and Chopra, K. (2004) Quercetin, an Anti-Oxidant Bioflavonoid, Attenuates Diabetic Nephropathy in Rats. Clinical and Experimental Pharmacology and Physiology, 31, 244-248. http://dx.doi.org/10.1111/j.1440-1681.2004.03982.X

[144] Bhutada, P., Mundhada, Y., Bansod, K., et al. (2010) Ameliorative Effect of Quercetin on Memory Dysfunction in Streptozotocin-Induced Diabetic Rats. Neurobiology of Learning and Memory, 94, 293-302. http://dx.doi.org/10.1016/j.nlm.2010.06.008

[145] Khaki, A., Fathiazad, F., Nouri, M., et al. (2010) Beneficial Effects of Quercetin on Sperm Parameters in Streptozotocin-Induced Diabetic Male Rats. Phytotherapy Research, 24, 1285-1291. http://dx.doi.org/10.1002/ptr.3100

[146] Kobori, M., Masumoto, S., Akimoto, Y. and Takahashi, Y. (2009) Dietary Quercetin Alleviates Diabetic Symptoms and Reduces Streptozotocin-Induced Disturbance of Hepatic Gene Expression in Mice. Molecular Nutrition \& Food Research, 53, 859-868. http://dx.doi.org/10.1002/mnfr.200800310

[147] Youl, E., Bardy, G., Magous, R., et al. (2010) Quercetin Potentiates Insulin Secretion and Protects INS-1 Pancreatic $\beta$-Cells against Oxidative Damage via the ERK1/2 Pathway. British Journal of Pharmacology, 161, 799-814. http://dx.doi.org/10.1111/j.1476-5381.2010.00910.X

[148] Zhao, L.R., Du, Y.J., Chen, L., Liu, Z.G., Pan, Y.H., Liu, J.F. and Liu, B. (2014) Quercetin Protects against High Glucose-Induced Damage in Bone Marrow-Derived Endothelial Progenitor Cells. International Journal of Molecular Medicine, 34, 1025-1031.

[149] Valensia, P., Devehath, C.L., Richards, J.L., et al. (2005) A Multicenter, Double-Blind, Safety Study of QR-333 for the Treatment of Symptomatic Diabetic Peripheral Neuropathy: A Preliminary Report. Journal of Diabetes and Its Complications, 19, 247-253. http://dx.doi.org/10.1016/j.jdiacomp.2005.05.011 